\title{
Gas Exchange, Water Use Efficiency, and Biomass Partitioning Among Geographic Sources of Acer saccharum subsp. saccharum and subsp. nigrum seedlings in Response to Water Stress
}

\author{
Richard J. Hauer ${ }^{1 *}$, Hongxu Wei ${ }^{2}$, Andrew K. Koeser ${ }^{3}$, and Jeffrey O. Dawson ${ }^{4}$ \\ College of Natural Resources, University of Wisconsin-Stevens Point, WI 54481, USA; rhauer@uwsp.edu; \\ 2 Northeast Institute of Geography and Agroecology, Chinese Academy of Sciences, Changchun 130102, \\ China; weihongxu@iga.ac.cn \\ 3 Associate Professor, University of Florida Gulf Coast Research and Education Center, 14625 CR 672, \\ Wimauma, FL 33598, USA; akoeser@ufl.edu \\ 4 Department of Natural Resources and Environmental Sciences, University of Illinois at Urbana/Champaign, \\ Urbana, IL 61801, USA; jdawson2@illinois.edu \\ * Correspondence: rhauer@uwsp.edu; Tel.: (1+715-346-3642)
}

\begin{abstract}
Responses to water stress were measured for sugar maple (Acer saccharum subsp. saccharum Marshall) sources from Oklahoma (Caddo sugar maple), Missouri, Tennessee, Ontario and a black maple (Acer saccharum subsp. nigrum F. Michx.) source from Iowa. Seedling sources were selected for differences in temperature and precipitation of their geographic origins. Seedlings were preconditioned through moist (watered daily) or dry (watered every 4-7 days) cycles and then exposed to prolonged water stress. Dry preconditioned sugar maple seedlings from Oklahoma, Missouri, and Tennessee, sources from warmer and/or drier climates with greater relative evapotranspiration potentials, declined less rapidly in net photosynthesis, stomatal conductance, and water use efficiency (WUE) as water stress increased than dry preconditioned seedlings from Ontario and Iowa having origins in cooler, moister climates. Under imposed water stress the Ontario and Iowa sourced seedlings increased their root to shoot ratios and decreased their specific leaf area, mechanisms for drought avoidance. However, no corresponding changes in these values occurred for Oklahoma, Missouri, and Tennessee sources. Results from this study suggest greater tolerance of water stress in the Oklahoma, Missouri and Tennessee ecotypes from the western and southern range of sugar maple resulted primarily with WUE rather than other water stress coping mechanisms.
\end{abstract}

Keywords: Abiotic Stress; Forestry; Tree Physiology; Plant Selection; Urban Forestry

\section{Introduction}

Sugar maple (Acer saccharum Marshall) trees provide wildlife benefits; serve as tribal, provincial, state and national cultural symbols; are a source for maple syrup; and are harvested for valuable wood products [1]. Additionally, sugar maple is commonly planted as urban and residential trees for their shade, stature, beautiful fall leaf color, and pleasing growth habit [2]. Sugar maple trees (Acer saccharum Marshall subsp. saccharum) have been regarded as susceptible to long-term water stress manifested through drought in forested environments in North America [1, 3, 4, 5, 6, 7, 8, 9]. Water stress leading to maple decline and death has also been reported in urban and peri-urban landscapes [10,11, 12, 13].

Sugar maple trees decline as a result of water stress has commonly been observed in native and planted stands, and ecotypes from the southwestern part of the species' range have been observed to possess greater resistance to water deficits than sugar maple ecotypes from the northern and eastern parts of the species' range [14, 15, 16, 17, 18, 19]. The Caddo sugar maple (Acer saccharum 'Caddo') from central Oklahoma USA is an example of a sugar maple ecotype with potentially greater drought resistance $[18,20]$. Thus, we selected and tested sugar maple seedlings representing presumptive ecotypes sourced 
from locales that varied in temperature and precipitation, and relative evapotranspiration potential [21].

Black maple (A. saccharum subsp. nigrum) trees, particularly from Iowa USA, have been speculated to possess greater resistance to water deficits compared to associated sugar maple trees and sugar maple from parts of its eastern range [22, 23, 24, 25, 26]. Such suggestions are based on topographic features and the fact that the average climatic conditions within black maples' range are warmer and drier than much of sugar maples' total range [27]. Several woody plant reference books focusing on tree selections for cultivation have suggested that black maple has greater tolerance to water stress than sugar maple $[28,29]$. In contrast, Dirr [2] observed that sugar and black maple trees in urban landscapes do not distinguishably differ in response to water deficits. Niinemets and Valladares [30] reviewed drought tolerance reports on 806 woody plants species from the Northern hemisphere, ranking ( 1 to 5 scale, 5 most tolerant) black maple more tolerant ( $3.35 \pm .35 \mathrm{SE}$ ) than sugar maple $(2.25 \pm .25 \mathrm{SE})$. Conflicting reports indicate a need for additional ecophysiological studies to elucidate functional and structural traits that might explain inconsistent observational reports of ecotypic variation in tolerance to water stress of sugar and black maples [31]. Further, Skepner and Krane [32] identified through RAPD-PCR analysis that black and sugar maple while genetically should be classified as subspecies, a geographical source distinction was detected resulting from a putative local environment effect.

Black and sugar maple trees in general grow naturally on a variety of sites, however, both prefer well-drained, mesic soils [1,33]. When they naturally occur in the same locale, black maple trees tend to occur on the more mesic sites, whereas sugar maple concurrently occurs on relatively drier sites [24, 34, 35]. For example, in western Indiana USA and eastern Illinois USA, black maple trees are typically restricted to more mesic deeper soils than sugar maple trees [36]. Furthermore, black maple trees in Iowa typically occur on north facing slopes or in areas with ample soil moisture, rather than on more xeric sites [37]. Thus, published reports differ in their assessments of sugar and black maples' general and specific abilities to withstand drought stress.

Field and greenhouse studies have been used to investigate water stress tolerance of sugar and black maples from different seed sources. Sources from the southwestern portion of the range of the species tend to have greater potential evapotranspiration than those from the northeastern part of the range [21]. Sugar maple trees from the southwestern part of its range were reported to have greater survival, resistance to water stress, and less leaf scorching than sources from the species eastern range [14, 16, 18]. Pair [18] observed less negative predawn water potential, less leaf scorch, and less leaf tatter following a summer drought in the Caddo sugar maple (Oklahoma source) and sugar maple cultivars ('Commemoration' and 'Legacy') sourced from the species' southern range, than sugar maple cultivars ('Bonfire' and 'Green Mountain') from more eastern locations in North America. An Iowa black maple source ('Green Column') was intermediate. Graves [23] determined in a seedling study that a west central Iowa black maple source had a greater capacity to withstand water stress than a native Minnesota USA sugar maple source from $275 \mathrm{~km}$ to the north and a location with relatively cooler summer temperatures $\left(\sim 1.5^{\circ} \mathrm{C}\right)$.

In additional to any potential genetic differences, questions remain as to whether mild water stress more common to certain sites can precondition changes in sugar and black maple to water stress $[38,39]$. Preconditioning can lead to increased physiological activity during water stress, changes in biomass portioning, and morphological development [40]. However, there are no reports in the literature on the effects of water stress preconditioning on key sugar maple seedling physiological and morphological adaptations in the context of ecotypical variation.

The aim of this study was to compare and determine seedling physiological and biomass allocation responses of sugar maple and black maple sources to water stress with or without water-stress preconditioning treatments. The following questions were posed: 1) how do sugar maple ecotypes vary in biomass partitioning, 2) what are the 
photosynthetic rates of sugar maple seedlings under contrasting soil moisture regimes, 3) what are the other foliar gas exchange rates of sugar maple seedlings under contrasting soil moisture regimes, 4) do sugar maple ecotypes differ in seedling water use efficiency (WUE) in response to water stress, and 5) do maple seed geographic sources produce seedlings that differ in water stress response to mild water stress preconditioning? We hypothesized that the southern and western sugar maple seedlings sourced from warmer, often drier locales in Oklahoma (Caddo sugar maple), Missouri, and Tennessee possess greater water stress resistance than sources from Ontario and Iowa (black maple). The Caddo sugar maple was predicted to have the highest net photosynthetic rate and water use efficiency (WUE) with increasing exposure to increasing water stress. Water use efficiency and net photosynthesis were predicted to decline more rapidly with water deficits in sugar maple seedlings from Ontario. Black maple was predicted to be more sensitive to water stress than the sugar maple sources from Missouri, Tennessee, and Oklahoma. We assumed that natural selection for water stress tolerance would have been most pronounced in maples from locations having drier, warmer climates.

\section{Materials and Methods}

\subsection{Seed source, germination, and establishment}

Experimental plants were grown from seed obtained from Sunshine Nursery (Clinton, OK) for the Oklahoma (Caddo) source originating from Red Rock Canyon; from Sheffield's Seed Company (Locke, NY) for the Tennessee, Missouri, and Ontario sources; and from Smith Nursery Co. (Charles City, IA) for the Iowa black maple source (Table 1). The seedlings exhibited morphological traits consistent with their taxonomic assignments and presumptive ecotypes. Stipules were observed on black maple at the base of the petiole, leaves had 3 prominent lobes and drooped, and the leaf underside was pubescent. The Ontario source's seedling leaves were generally 5 lobed with narrow sinuses, glabrous underneath, and were the thinnest of all geographic sources. The Missouri source had 35 lobed leaves with intermediate pubescence. Leaves from the Tennessee source had the most pubescence producing a whitish appearance along the mid rib and veins, and were 3-5 lobed, with deep sinuses. The Caddo source's leaves were generally 3-5 lobed, had a thicker waxy appearance, and an intermediate level of pubescence.

In late October seeds were surface sterilized in $10 \% \mathrm{H}_{2} \mathrm{O}_{2}$ for 15 minutes and soaked in $\mathrm{dH}_{2} \mathrm{O}$ for 14 days at $3-4^{\circ} \mathrm{C}$. Moist seeds were stratified in the dark at $3-4^{\circ} \mathrm{C}$ for 45 days [41]. Three seeds per container were planted in late December in $2.4 \mathrm{~L}(10 \mathrm{~cm} \times 30 \mathrm{~cm}$ PVC plastic pipe with 2-mm nylon mesh over open bottoms to allow drainage). These plant containers were filled with a steam pasteurized 2:2:1 (v/v/v) peat moss, coarse sand, and Drummer silty clay loam soil mix [44]. Seedlings were thinned from pots after 3 weeks leaving 1 per container. All seedlings were grown for an additional 7 weeks and watered daily or as needed to maintain moist soil prior to allocation to experimental subsets. A total 120 containers were grown in a random arrangement of a greenhouse bench. Experimental plants were randomly allocated to subsets as described later for destructive biomass and morphology measurements before $(n=20)$ and after moisture stress preconditioning $(n=40)$, plant gas exchange measurements $(n=30)$, and plant water relation $(n=30)$ measurements (Figure 1). 
Table 1. Sources of Acer saccharum subsp. saccharum and Acer saccharum subsp. nigrum (Iowa), approximate location, and climatic conditions.

\begin{tabular}{|c|c|c|c|c|c|c|c|}
\hline $\begin{array}{l}\text { Seed Source } \\
\text { (Location) }\end{array}$ & $\begin{array}{c}\text { Latitude } \\
\left({ }^{\circ} \mathrm{N}\right)\end{array}$ & $\begin{array}{c}\text { Longitude } \\
\left({ }^{\circ} \mathbf{W}\right) \\
\end{array}$ & $\begin{array}{c}\text { Mean } \\
\text { July } \\
\text { Temp } \\
\left({ }^{\circ} \mathrm{C}\right) \\
\end{array}$ & $\begin{array}{c}\text { Mean } \\
\text { Annual } \\
\text { Temp } \\
\left({ }^{\circ} \mathrm{C}\right) \\
\end{array}$ & $\begin{array}{c}\text { Max } \\
\text { Annual } \\
\text { Temp } \\
\left({ }^{\circ} \mathrm{C}\right)\end{array}$ & $\begin{array}{c}\text { Min } \\
\text { Annual } \\
\text { Temp } \\
\left({ }^{\circ} \mathrm{C}\right)\end{array}$ & $\begin{array}{c}\text { Total Annual } \\
\text { Precipitation } \\
\quad(\mathrm{mm})\end{array}$ \\
\hline $\begin{array}{l}\text { Oklahoma }^{1} \\
\text { (Caddo Co., OK) }\end{array}$ & 35.3736 & -98.3775 & 27.4 & 14.9 & 22.1 & 7.9 & 849 \\
\hline $\begin{array}{l}\text { Tennessee }^{1} \text { (Haywood } \\
\text { Co., } \mathrm{TN})\end{array}$ & 35.5894 & -89.2586 & 27.0 & 15.8 & 21.4 & 10.2 & 1374 \\
\hline $\begin{array}{l}\text { Missouri }^{1} \\
\text { (Texas Co., MO) }\end{array}$ & 37.5544 & -91.8830 & 24.9 & 12.7 & 19.0 & 6.4 & 1141 \\
\hline $\begin{array}{l}\text { Iowa }^{1} \\
\text { (Floyd Co., IA) }\end{array}$ & 43.0604 & -92.6717 & 22.4 & 8.1 & 13.4 & 2.7 & 884 \\
\hline $\begin{array}{l}\text { Ontario }^{2} \\
\text { (Ottawa Canada) }\end{array}$ & 45.3833 & -75.7167 & 21.2 & 6.6 & 11.4 & 1.9 & 920 \\
\hline
\end{tabular}

${ }^{1}$ Climatological data (1981-2010) from National Oceanic and Atmospheric Administration

(https://www.ncdc.noaa.gov/cdo-web/) records or ${ }^{2}$ Government of Canada (https://climate.weather.gc.ca/) from a recording station in nearest proximity to seed source location.

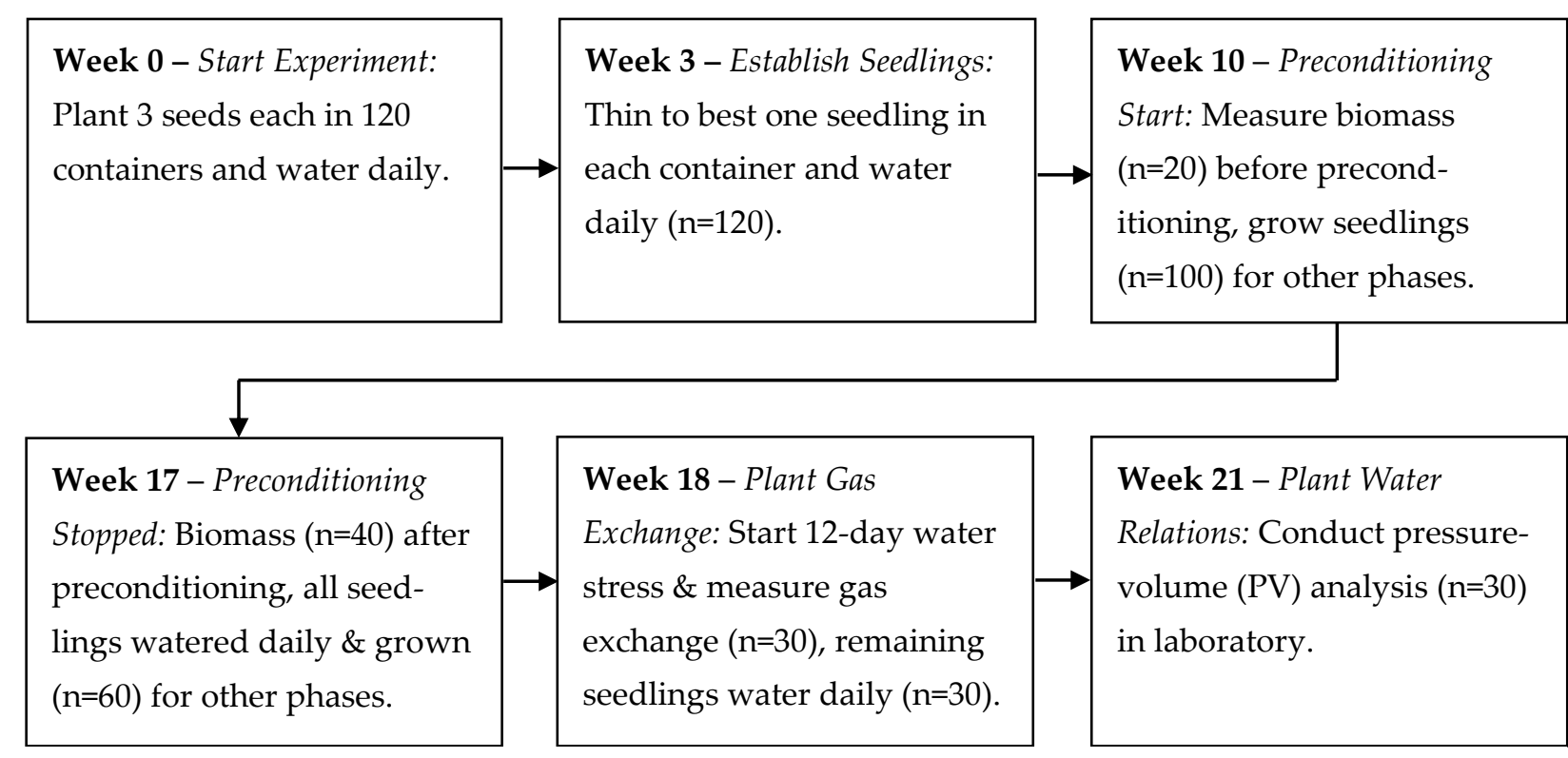

Figure 1. Timeline of experiment with key phases (in italics, e.g., start of experiment) and outcomes. Preconditioning was the daily watering or watering of seedlings after exhibiting leaf wilting and then rewater and continue this during the 7-week preconditioning period. Each biomass measurement (Week 10 and Week 17) was a destructive harvest with 4 reps per each of 5 seed sources and preconditioning treatment. Gas exchange and plant water relations each had 3 replications per each seed source and preconditioning combination. 
Supplemental light from Sylvania L41000 metal halide lamps (GTE Sylvania, Inc., Manchester, $\mathrm{NH}$ ) was provided automatically when ambient radiation decreased below $400 \mu \mathrm{mol} \times \mathrm{m}^{-2} \cdot \mathrm{s}^{-1}$ of photosynthetic photon flux density (PPFD) as measured with a Li-Cor Quantum Sensor (Li-Cor, Lincoln, NE) during a 16-hour photoperiod. A 16-hour photoperiod was used to promote active growth and minimize bud set in sugar maple [42, 43]. Greenhouse temperatures were $22^{\circ} \mathrm{C}$ (days) and $19^{\circ} \mathrm{C}$ (nights) $\pm 3^{\circ} \mathrm{C}$. During the establishment period (10 weeks), seedlings were watered daily or as needed and fertilized weekly with a 20:20:20 (nitrogen [N] : phosphorus [P] : potassium [K]) Peter's brand (Allentown, $\mathrm{PA}$ ) fertilizer solution ( $\mathrm{N}$ at $473 \mathrm{ppm}$ ) supplemented with a full-strength Hoagland's [45] micronutrient solution using Sprint 330 (BASF, Research Triangle Park, NC) as an iron chelating agent.

\subsection{Seedling preconditioning}

Ten-week-old seedlings grown as described above were subjected to 2 preconditioning treatments in early March for 7 weeks. Only actively growing seedlings that had not set a terminal bud were selected for random allocation to treatments for all five seedling sources. Seedlings were preconditioned through either a moist regime consisting of daily watering to soil capacity or subjected to a series of drying cycles for the dry regime in which all seedlings were then rewatered to soil water-holding capacity for 2 days after flaccid leaves were observed. Dry cycles (watering withheld) were used to mimic natural water stress and to see if it could induce greater tolerance to water stress. Dry cycles lasted between 4 and 7 days with most lasting 5 days. Seedlings were fertilized 3 times during the preconditioning period with the fertilizer solution described above.

2.3 Seedling mass and leaf area

The dry mass of leaf, stem, shoot (leaf and stem combined), and root tissue along with leaf area were measured for a subset sample of 4 actively growing seedlings per treatment prior to $(n=20)$ and after preconditioning $(n=40)$. Seedling mass was determined from tissue dried (for $48-72$ hours) to consistent mass at $70^{\circ} \mathrm{C}$. Total leaf area per seedling was estimated using a leaf area meter (Li-Cor Model 3100, Lincoln, NE). Seedling height was measured after preconditioning.

\subsection{Plant water relations and gas exchange}

Following the 7-week preconditioning period, seedlings in all 10 treatment combinations ( 2 preconditioning regimes $\times 5$ seed sources) were watered daily for 7 days. Watering was then stopped and then daily gas exchange measurements including net photosynthesis $\left(\mathrm{A}, \mu \mathrm{mol} \mathrm{CO} \cdot \mathrm{m}^{-2} \cdot \mathrm{s}^{-1}\right)$, stomatal conductance $\left(\mathrm{G}_{\mathrm{s}}, \mathrm{mol} \mathrm{H} \mathrm{H}_{2} \mathrm{O} \cdot \mathrm{m}^{-2} \cdot \mathrm{s}^{-1}\right)$, transpiration $(\mathrm{E}, \mathrm{mol}$ $\left.\mathrm{H}_{2} \mathrm{O} \cdot \mathrm{m}^{-2} \cdot \mathrm{s}^{-1}\right)$, intercellular $\mathrm{CO}_{2}$ concentration $(\mathrm{Ci}, \mathrm{ppm})$, ambient $\mathrm{CO}_{2}$ concentration $(\mathrm{Ca}$, $\mathrm{ppm}$ ), and instantaneous water use efficiency (WUE, $\mu \mathrm{mol} \cdot \mathrm{mol}^{-1}$ ) derived from $\mathrm{A} \cdot \mathrm{E}^{-1} \mathrm{oc}-$ curred on 3 seedlings per treatment using a Li-Cor model 6200 portable photosynthesis system and model 6250 infrared gas analyzer (LI-Cor Inc., Lincoln NE) for 3 replications $(n=30)$ for these measurements. Measurements were made on the first fully expanded leaf, corresponding to a plastochron age of 4-6. These leaves had formed during the preconditioning period. Measurements were made daily between 9:30 and 10:30 A.M. central standard time in an environmentally controlled research greenhouse located in Urbana, Illinois $(40.1106 \mathrm{~N}, 88.2073 \mathrm{~W})$. This time period corresponded to peak $\mathrm{CO}_{2}$ exchange rates during trials with seedlings tested under both moist and dry conditions (data not shown). Measurements were stopped after day 12 as net photosynthesis closely approached 0 for all source and treatment combinations. Diurnal measurements also occurred on days 0,3 , 5, 6, 7, and 9 with all plants measured every 2 hours during daylight hours. Artificial lighting was employed on days 1 and 6 to compensate for cloudy conditions to maintain a light intensity at seedling level at a minimum PPFD of $400 \mu \mathrm{mol} \times \mathrm{m}^{-2} \times \mathrm{S}^{-1}$. This was a level found from previous testing to result in maximum photosynthetic rate (data not shown). Gas exchange measurements were derived from the mean of 3 samples each over a 10second period from a leaf in a quarter-liter chamber for approximately 1 minute.

Daily measurements of leaf water potential were not taken due to phloem bubbling which obscures end-point recognition of xylem exudation of the petiole in sugar maple and also not to reduce leaf area of seedlings during this measurement period [5], 
necessitating stem rather than petiole measurements of water potential. Stem samples with leaves were used for pressure-volume (PV) analysis to estimate leaf water potential and the osmotic potential at full turgor $\left(\mathrm{Y}_{100}\right)$, osmotic potential at zero turgor $\left(\mathrm{Y}_{0}\right)$, and relative water content at zero turgor. Seedlings were watered daily for 4 weeks after preconditioning was terminated. Seedlings $(n=30)$ used for PV analysis were watered to soil capacity and placed in a dark room overnight. The following morning $10 \mathrm{~cm}$ long stems that contained 6-8 leaves were cut under low light conditions, weighed immediately afterwards to estimate the saturated tissue mass, an estimate of the water potential at full saturation was made, and the free transpiration PV technique was used to estimate PV parameters [46] using a pressure chamber (Model 3005, Soil Moisture Equipment Corp., Santa Barbara, CA).

\subsection{Experimental design and statistical analysis}

The experimental design was a $5 \times 2$ factorial combination that included seedlings from 5 seed sources that were preconditioned through either a moist or dry watering regime. Containers were arranged in a completely randomized manner on greenhouse benches. All statistical analyses were performed using IBM SPSS version 25 (IBM Corp., Armonk, N.Y., USA). Mean differences in biomass portioning and leaf water relations were analyzed using an ANOVA. A generalized least squares repeated measures mixed model was used to analyze temporal changes in gas exchange measurements. Mean differences during each day for leaf water relations and gas exchange were analyzed using ANOVA. Tests for model assumptions were made and no correction of data was needed. Means were separated in all cases with a Fisher's Protected LSD at the $a=0.05$ probability level for biomass measurements. A Duncan test was used for the leaf water relations measurements due to an unequal sample size.

\section{Results}

\subsection{Seedling mass and height}

Prior to preconditioning, 10-week-old seedlings were similar in total leaf area, leaf mass, stem mass, shoot mass, and R:S (Table 2). Root mass was significantly greater $(\mathrm{p}=0.047)$ in the Iowa (black maple) source, nearly 2 times more than the other 4 ecotypes. Specific leaf area was greatest $(\mathrm{p}=0.029)$ in Caddo and Tennessee sources.

Significant differences occurred among sources in shoot and root growth of 17-weekold seedlings after preconditioning (Table 3). The exception was no difference in plant height among sources $(p=0.174)$. Seed source had the greatest significance $(p<0.02)$ associated with the difference in the mass of leaf, stem, shoot, and root attributes. Preconditioning had a significant effect $(\mathrm{p}<0.05)$ on leaf area and leaf mass attributes with a $42 \%$ decline in leaf area and a $26 \%$ decrease in leaf mass of black maple. Likewise, black maple had less stem and shoot mass. Root mass was 2.3 times greater $(\mathrm{p}=0.002)$ in black maple than the sugar maple sources. The R:S of the Iowa black maple and Ontario sugar maple sources prior to preconditioning (10 weeks) and under moist preconditioning (17 weeks) were similar (Tables 2, 3). The Iowa and Ontario sources increased $(\mathrm{p}=0.002)$ their R:S and decreased $(\mathrm{p}<0.001)$ their specific leaf area (SLA) under the dry preconditioning regime. While the Caddo, Missouri, and Tennessee sources R:S and SLA did not statistically change, resulting in a significant $(\mathrm{p}=0.002)$ source by preconditioning interaction. Black maple apparently reduced shoot mass and proportionally allocated biomass to root growth in response to preconditioning water stress. There was no discernible difference among maple seedlings from all sources in leaf wilting observed among sources during a dry cycle. 
Table 2. Morphological characteristics of 10-week-old Acer saccharum subsp. saccharum and Acer saccharum subsp. nigrum (Iowa) seedlings by source prior to preconditioning through moist or dry cycles.

\begin{tabular}{|c|c|c|c|c|c|c|c|}
\hline Seed source & $\begin{array}{l}\text { Total leaf } \\
\text { area }\left(\mathrm{cm}^{2}\right)\end{array}$ & $\begin{array}{l}\text { Leaf } \\
\text { mass (g) }\end{array}$ & $\begin{array}{l}\text { Stem } \\
\text { mass (g) }\end{array}$ & $\begin{array}{l}\text { Shoot } \\
\text { mass (g) }\end{array}$ & $\begin{array}{l}\text { Root } \\
\text { mass }(g)^{1}\end{array}$ & $\begin{array}{l}\text { Root:Shoot } \\
\text { mass ratio }\end{array}$ & $\begin{array}{l}\text { Specific } \\
\text { leaf area } \\
\left(\mathrm{cm}^{2} \times \mathrm{g}^{-1}\right)^{1}\end{array}$ \\
\hline Caddo & 319 & 1.21 & 0.26 & 1.47 & $0.27 \mathrm{~b}$ & 0.17 & $279 \mathrm{~b}$ \\
\hline Iowa & 464 & 2.26 & 0.70 & 2.96 & $0.53 \mathrm{a}$ & 0.22 & $212 \mathrm{a}$ \\
\hline Missouri & 490 & 2.04 & 0.65 & 2.70 & $0.29 \mathrm{~b}$ & 0.11 & $243 \mathrm{ab}$ \\
\hline Ontario & 405 & 1.58 & 0.22 & 1.81 & $0.30 \mathrm{~b}$ & 0.17 & $253 \mathrm{ab}$ \\
\hline Tennessee & 363 & 1.26 & 0.47 & 1.78 & $0.22 \mathrm{~b}$ & 0.12 & $287 \mathrm{~b}$ \\
\hline Means & 408 & 1.67 & 0.46 & 2.14 & 0.32 & 0.16 & 255 \\
\hline $\mathrm{F}(4,15)$ value & 0.950 & 1.848 & 1.848 & 1.769 & 3.110 & 2.082 & 3.643 \\
\hline Model $^{2}$ & 0.462 & 0.172 & 0.172 & 0.188 & 0.047 & 0.134 & 0.029 \\
\hline
\end{tabular}

${ }_{1}^{1}$ Means $(n=20)$ in a column with same letter are not different $(\mathrm{p}>0.05)$ with a Fisher's Protected LSD.

${ }^{2}$ Significance probabilities from the F statistic from an ANOVA. Significant values $(\mathrm{p}<0.05)$ in bold.

Table 3. Morphological characteristics after 7 weeks of preconditioning for 17-week-old Acer saccharum subsp. saccharum and Acer saccharum subsp. nigrum (Iowa) seedling by preconditioning (Precond.) through moist or dry cycles.

\begin{tabular}{|c|c|c|c|c|c|c|c|c|c|}
\hline Seed source & $\begin{array}{l}\text { Precon- } \\
\text { dition- } \\
\text { ing re- } \\
\text { gime }\end{array}$ & $\begin{array}{l}\text { Leaf } \\
\text { area } \\
\left(\mathrm{cm}^{2}\right)^{1}\end{array}$ & $\begin{array}{l}\text { Leaf } \\
\text { mass }(g)^{1}\end{array}$ & $\begin{array}{l}\text { Stem } \\
\text { mass } \\
(\mathrm{g})^{1}\end{array}$ & $\begin{array}{l}\text { Shoot } \\
\text { mass } \\
(\mathrm{g})^{1}\end{array}$ & $\begin{array}{l}\text { Root } \\
\text { mass } \\
(\mathrm{g})^{1} \\
\end{array}$ & $\begin{array}{l}\text { Root:Shoot } \\
\text { mass ratio }^{1}\end{array}$ & $\begin{array}{l}\text { Specific } \\
\text { leaf area } \\
\left(\mathrm{cm}^{2} \times \mathrm{g}^{-1}\right)^{1}\end{array}$ & $\begin{array}{l}\text { Height } \\
(\mathrm{cm})^{1}\end{array}$ \\
\hline Caddo & Dry & $1216 \mathrm{ab}$ & $5.40 \mathrm{abc}$ & $2.14 \mathrm{a}$ & $7.55 \mathrm{a}$ & $1.33 \mathrm{ab}$ & $0.19 a b$ & 228 ef & 57.6 \\
\hline Caddo & Moist & $1415 \mathrm{ab}$ & $6.82 \mathrm{abc}$ & $3.15 \mathrm{ab}$ & $9.97 \mathrm{ab}$ & $2.69 \mathrm{bc}$ & $0.27 \mathrm{~b}$ & 209 cde & 66.9 \\
\hline Iowa & Dry & 1118 a & 7.83 cde & $3.33 \mathrm{ab}$ & $11.16 \mathrm{ab}$ & $4.69 \mathrm{~d}$ & $0.44 \mathrm{c}$ & $144 \mathrm{a}$ & 43.7 \\
\hline Iowa & Moist & 1941 c & $10.53 \mathrm{e}$ & $6.17 \mathrm{c}$ & $16.70 \mathrm{c}$ & $3.99 \mathrm{~cd}$ & $0.23 \mathrm{ab}$ & 187 bcd & 91.6 \\
\hline Missouri & Dry & $1440 \mathrm{abc}$ & $6.97 \mathrm{abcd}$ & $3.96 \mathrm{abc}$ & $10.93 \mathrm{ab}$ & $1.72 \mathrm{ab}$ & $0.16 \mathrm{ab}$ & 206 cde & 86.2 \\
\hline Missouri & Moist & 1696 bc & $9.24 \mathrm{de}$ & 5.14 bc & $14.39 \mathrm{bc}$ & $2.61 \mathrm{bc}$ & $0.18 \mathrm{bc}$ & $183 \mathrm{bc}$ & 81.2 \\
\hline Ontario & Dry & $1280 \mathrm{ab}$ & $7.39 \mathrm{bcd}$ & $3.16 \mathrm{ab}$ & $10.55 \mathrm{ab}$ & $2.68 \mathrm{bc}$ & $0.27 b$ & $171 \mathrm{ab}$ & 55.8 \\
\hline Ontario & Moist & $1544 \mathrm{abc}$ & 7.40 bcde & $2.96 \mathrm{ab}$ & $10.37 \mathrm{ab}$ & $2.02 \mathrm{ab}$ & $0.19 \mathrm{ab}$ & 209 cde & 67.8 \\
\hline Tennessee & Dry & 1096 a & $4.55 \mathrm{a}$ & $2.53 \mathrm{a}$ & $7.08 \mathrm{a}$ & 0.89 a & $0.13 \mathrm{a}$ & $244 \mathrm{f}$ & 81.0 \\
\hline Tennessee & Moist & $1078 \mathrm{a}$ & $4.63 \mathrm{ab}$ & $2.50 \mathrm{a}$ & $7.13 \mathrm{a}$ & $1.36 \mathrm{ab}$ & $0.19 \mathrm{ab}$ & 232 ef & 70.7 \\
\hline Means & & 1374 & 7.06 & 3.53 & 10.59 & 2.42 & 0.23 & 201 & 70.4 \\
\hline F $(9,28)$ value & & 2.579 & 4.209 & 2.452 & 3.453 & 5.592 & 4.106 & 10.582 & 1.566 \\
\hline Model$^{2}$ & & 0.026 & 0.002 & 0.033 & 0.006 & $<0.001$ & 0.002 & $<0.001$ & 0.174 \\
\hline Seed source $^{2}$ & & 0.071 & $<0.001$ & 0.020 & 0.002 & $<0.001$ & 0.002 & $<0.001$ & 0.358 \\
\hline Preconditioning 2 & & 0.014 & 0.044 & 0.082 & 0.051 & 0.429 & 0.465 & 0.374 & 0.188 \\
\hline $\begin{array}{l}\text { Seed source } \times \\
\text { Preconditioning } 2\end{array}$ & & 0.207 & 0.538 & 0.397 & 0.452 & 0.226 & 0.015 & 0.002 & 0.157 \\
\hline
\end{tabular}

${ }^{2}$ Means (1




\subsection{Plant water relations and gas exchange}

\subsubsection{Daily gas exchange analysis}

The repeated measures analysis showed all seed sources exhibited significant $(\mathrm{P}<0.001)$ declines in $\mathrm{A}, \mathrm{Gs}, \mathrm{E}$, and WUE and an increase in $\mathrm{Ci}$ and $\mathrm{Ci} / \mathrm{Ca}$ over time as water was withheld (Figure 2). A significant day $\times$ source interaction occurred in $\mathrm{A}$ $(\mathrm{p}=0.002)$, $\mathrm{Gs}(\mathrm{P}<0.001)$, and $\mathrm{E}(\mathrm{P}<0.001)$. A significant $(\mathrm{P}<0.05)$ day $\times$ source $\times$ preconditioning interaction occurred in A and WUE. The interactions indicate that the sources responded differently as water stress progressed and that preconditioning influenced a source's response to the imposed water stress. Significant $(p=0.01)$ between subject effects were detected for $\mathrm{Ci}$ and $\mathrm{Ci} / \mathrm{Ca}$ among the seed sources.

The Iowa (black maple) and Ontario sources responded similarly in either preconditioning regime (Figure 2). The dry preconditioned Caddo, Missouri, and Tennessee sources as a group responded differently from moist preconditioned seedlings from these sources and from the Iowa and Ontario sources from either preconditioning regime, exhibiting a higher A, Gs, and WUE together with a lower Ci/Ca during days 5-8 after withholding watering than the other source and preconditioning combinations (Figure 2). Dry preconditioned seedlings from the Iowa source initially declined more rapidly in A, Gs, and WUE than moist-preconditioned seedlings of the Iowa source. However, after day 4 , seedlings from the Iowa source under both preconditioning regimes declined similarly. The A, Gs, and WUE of moist-preconditioned Caddo and Missouri seedlings declined more rapidly than dry preconditioned seedlings from those sources. The Caddo source typically maintained the highest $\mathrm{A}$ and Gs during the initial days of drying.

Significant differences $(p<0.001)$ were detected among seed sources with an ANOVA for all plant water relations parameters and gas exchange measurements on days 7 and 8 (Tables 4 and 5). A significant $(\mathrm{p}<0.001)$ source $\times$ ๑preconditioning interaction also occurred in the A, Gs, and E on days 7 and 8 . The statistically significant interaction occurred because the Caddo and Missouri sugar maple sources responded differently to the 2 preconditioning regimes, in that the wet preconditioned seedlings from these sources had lower gas exchange than the dry preconditioned seedlings. In contrast, seedlings from the Ontario source and Iowa black maple source from either preconditioning regime responded similarly. WUE was greater in the dry preconditioned Caddo and Missouri sources. The Tennessee source had the highest A, Gs, and WUE and curiously these maxima occurred in the moist preconditioned treatment.

\subsubsection{Diurnal measurements}

The A and Gs were highest in the dry preconditioned Caddo, Iowa, and Ontario sources and WUE was approximately similar for all sources from mid-morning to late afternoon during the initial few days after withholding watering (data not shown). As time increased, the $\mathrm{A}, \mathrm{Gs}$, and WUE decreased more rapidly and the $\mathrm{Ci} / \mathrm{Ca}$ increased more rapidly for the Iowa and Ontario sources than the dry preconditioned Caddo, Missouri, and Tennessee sugar maple sources. Diurnal response curves for $G_{s}$ and $E$ were similar to, and consistent with, A and WUE. The dry and moist preconditioned Ontario and Iowa sources responded similarly in measured gas exchange parameters. Moist preconditioned Caddo and Missouri seedlings declined more rapidly than dry preconditioned seedlings from these sources, but they responded similarly to the moist preconditioned Ontario and Iowa sources. Similar to the daily measurements, the Tennessee moist preconditioned seedlings maintained the highest diurnal A, Gs, E, and WUE over the course of the imposed water stress through the last diurnal measurement on day 9 .

\subsection{Leaf water potential}

Leaf water potential measurements did not differ between preconditioning regimes for RWC ( $p=0.126), Y_{100}(p=0.695)$, and $Y_{0}(p=0.505)$. So, the moist and dry preconditioned seedlings were pooled together for statistical analysis. The $Y_{100}$ and $Y_{0}$ were significantly different among the sources (Table 6). The and $\mathrm{Y}_{100}$ was lower $(\mathrm{p}=0.003)$ in the Iowa source $(-1.51)$ and Ontario (-1.42) than in the Missouri (-1.21), Caddo (-1.18), and Tennessee (-0.98) sources. This pattern was similar with $\mathrm{Y}_{0}$ and lower $(\mathrm{p}=0.003)$ in the Iowa source $(-1.68)$ and Ontario (-1.56) than in the Missouri (-1.35), Caddo (-1.34), and Tennessee (-1.12) 
sources. The relative water content at zero turgor differed $(\mathrm{p}=0.007)$ among sources being lowest in the Caddo sugar maple (93.1\%) and highest in the Tennessee source (95.0\%).

\section{Discussion}

This study revealed physiological and morphological patterns of response to water stress among sugar and black maple sources from locations with differing climatic conditions. Sugar maple ecotypes from warmer southwesterly locations (e.g., Oklahoma, Missouri, and Tennessee) responded similarly to imposed water stress. They were less sensitive to water stress than the more northerly Ontario and Iowa (black maple) sources. We hypothesized the Oklahoma source (Caddo) would exhibit the greatest resistance to water stress since the Caddo source is approximately $580 \mathrm{~km}$ southwest of the Missouri source

Table 4. Net photosynthesis (A, $\left.\mu \mathrm{mol} \mathrm{CO}_{2} \times \mathrm{m}^{-2} \times \mathrm{S}^{-1}\right)$, leaf conductance to water vapor (Gs, mol $\left.\mathrm{H}_{2} 0 \times \mathrm{m}^{-2} \times \mathrm{s}^{-1}\right)$, transpiration $\left(\mathrm{E}, \mathrm{mol} \mathrm{H} 20 \times \mathrm{m}^{-2} \times \mathrm{S}^{-1}\right)$, instantaneous water use efficiency (WUE, $\mathrm{Ps} \times \mathrm{E}^{-1}$ ), and intercellular to ambient $\mathrm{CO}_{2}$ concentrations $\left(\mathrm{Ci} / \mathrm{Ca}, \mathrm{ppm} \times \mathrm{ppm}^{-1}\right)$ on day 7 of withholding watering for Acer saccharum subsp. saccharum and Acer saccharum subsp. nigrum (Iowa) sources by preconditioning (Precond.) through moist or dry cycles.

Precond.

\begin{tabular}{|c|c|c|c|c|c|c|}
\hline Seed source & regime & $\mathrm{A}^{1}$ & $\mathrm{Gs}^{1}$ & $\mathrm{E}^{1}$ & WUE$^{1}$ & $\mathrm{Ci} / \mathrm{Ca}^{1}$ \\
\hline Caddo & Dry & $2.74 \mathrm{~d}$ & $0.039 \mathrm{~d}$ & $0.79 \mathrm{ab}$ & $3.44 \mathrm{~d}$ & $0.65 \mathrm{a}$ \\
\hline Caddo & Moist & $1.73 \mathrm{c}$ & $0.032 \mathrm{bc}$ & $0.67 \mathrm{bcd}$ & $2.60 \mathrm{c}$ & $0.72 \mathrm{bc}$ \\
\hline Iowa & Dry & $0.86 \mathrm{a}$ & $0.025 \mathrm{a}$ & $0.52 \mathrm{~d}$ & $1.59 \mathrm{a}$ & 0.82 ef \\
\hline Iowa & Moist & $1.07 \mathrm{ab}$ & $0.027 \mathrm{a}$ & $0.57 \mathrm{~cd}$ & $1.80 \mathrm{ab}$ & 0.80 def \\
\hline Missouri & Dry & $2.56 \mathrm{~d}$ & $0.038 \mathrm{~cd}$ & $0.75 \mathrm{bc}$ & $3.33 \mathrm{~d}$ & $0.67 \mathrm{ab}$ \\
\hline Missouri & Moist & $0.81 \mathrm{a}$ & $0.025 \mathrm{a}$ & $0.53 \mathrm{~d}$ & $1.27 \mathrm{a}$ & $0.84 \mathrm{f}$ \\
\hline Ontario & Dry & $1.41 \mathrm{abc}$ & $0.029 \mathrm{ab}$ & $0.59 \mathrm{~cd}$ & $2.37 \mathrm{bc}$ & $0.75 \mathrm{~cd}$ \\
\hline Ontario & Moist & $1.50 \mathrm{bc}$ & $0.030 \mathrm{ab}$ & $0.58 \mathrm{~cd}$ & $2.42 \mathrm{bc}$ & $0.76 \mathrm{cde}$ \\
\hline Tennessee & Dry & $2.51 \mathrm{~d}$ & $0.035 \mathrm{bc}$ & $0.67 \mathrm{bcd}$ & $3.67 \mathrm{~d}$ & $0.65 \mathrm{a}$ \\
\hline Tennessee & Moist & $3.87 \mathrm{e}$ & $0.051 \mathrm{e}$ & $1.00 \mathrm{a}$ & $3.88 \mathrm{~d}$ & $0.62 \mathrm{a}$ \\
\hline Means & & 1.91 & 0.033 & 0.67 & 2.64 & 0.73 \\
\hline Standard error & & 0.12 & 0.001 & 0.018 & 0.12 & 0.01 \\
\hline F $(9,80)$ value & & 20.148 & 13.487 & 17.040 & 13.103 & 12.531 \\
\hline Model $^{2}$ & & $<0.001$ & $<0.001$ & $<0.001$ & $<0.001$ & $<0.001$ \\
\hline Seed Source ${ }^{2}$ & & $<0.001$ & $<0.001$ & $<0.001$ & $<0.001$ & $<0.001$ \\
\hline Preconditioning 2 & & 0.112 & 0.845 & 0.869 & 0.003 & $<0.001$ \\
\hline Seed Source $x$ & & $<0.001$ & $<0.001$ & $<0.001$ & $<0.001$ & $<0.001$ \\
\hline Preconditioning ${ }^{2}$ & & & & & & \\
\hline
\end{tabular}

${ }^{1}$ Means ( $\left.\mathrm{n}=30\right)$ in a column with same letter are not different ( $\left.\mathrm{p}>0.05\right)$ with a Fisher's Protected LSD.

${ }^{2}$ Significance probabilities from the F statistic from an ANOVA. Significant values $(p<0.05)$ bold. 
and $770 \mathrm{~km}$ west of the Tennessee source. But we did not find that to be the case, perhaps due to the relatively cooler and moister microclimate inside Red Rock Canyon where the Caddo sugar maple occurs as a relict sugar maple population dating from a cooler, moister period prior to 5,000 y BP. The canyon microclimate is similar to the climate of forests containing sugar maple trees $300 \mathrm{~km}$ eastward near the Oklahoma and Arkansas border [47]. The long-term mean July temperature is similar among the southwestern sites (25 to $27^{\circ} \mathrm{C}$ ) and cooler in the more northerly study locations $\left(21\right.$ to $\left.22^{\circ} \mathrm{C}\right)$. At least at the seedling level, there may be no difference among the Caddo sugar maple and other sugar maple trees from the species' southwestern range. However, the Caddo sugar maple was shown to have superior water stress resistance to the 'Legacy' sugar maple cultivar on dry sites in Kansas [48]. Even though the Caddo sugar maple was failed to demonstrate superior water stress resistance over the other 4 sources, seedlings from this region, Missouri, and Tennessee did possess greater water stress resistance than sources from Ontario and Iowa (black maple).

Table 5. Net photosynthesis (A, $\mu \mathrm{mol} \mathrm{CO}_{2} \times \mathrm{m}^{-2} \times \mathrm{s}^{-1}$ ), leaf conductance to water vapor (Gs, $\left.\mathrm{mol} \mathrm{H}_{2} 0 \times \mathrm{m}^{-2} \times \mathrm{s}^{-1}\right)$, transpiration $\left(\mathrm{E}, \mathrm{mol} \mathrm{H} 20 \times \mathrm{m}^{-2} \times \mathrm{s}^{-1}\right.$ ), instantaneous water use efficiency (WUE, $\mathrm{Ps} \times \mathrm{E}^{-1}$ ), and intercellular to ambient $\mathrm{CO}_{2}$ concentrations $\left(\mathrm{Ci} / \mathrm{Ca}, \mathrm{ppm} \times \mathrm{ppm}^{-1}\right)$ on day 8 of withholding watering for Acer saccharum subsp. saccharum and Acer saccharum subsp. nigrum (Iowa) sources by preconditioning (Precond.) through moist or dry cycles.

\begin{tabular}{lllllll} 
Seed source & Precond. & $\mathrm{A}^{1}$ & $\mathrm{Gs}^{1}$ & $\mathrm{E}^{1}$ & WUE $^{1}$ & $\mathrm{Ci} / \mathrm{Ca}^{1}$ \\
& Regime & & & & & \\
\hline Caddo & Dry & $2.01 \mathrm{~b}$ & $0.034 \mathrm{de}$ & $0.71 \mathrm{~cd}$ & $2.81 \mathrm{c}$ & $0.71 \mathrm{~b}$ \\
Caddo & Moist & $1.17 \mathrm{a}$ & $0.027 \mathrm{bc}$ & $0.60 \mathrm{bc}$ & $1.95 \mathrm{~b}$ & $0.78 \mathrm{c}$ \\
Iowa & Dry & $0.94 \mathrm{a}$ & $0.025 \mathrm{abc}$ & $0.55 \mathrm{ab}$ & $1.58 \mathrm{ab}$ & $0.82 \mathrm{~cd}$ \\
Iowa & Moist & $0.71 \mathrm{a}$ & $0.024 \mathrm{abc}$ & $0.52 \mathrm{ab}$ & $1.36 \mathrm{ab}$ & $0.84 \mathrm{~cd}$ \\
Missouri & Dry & $2.48 \mathrm{~b}$ & $0.036 \mathrm{e}$ & $0.75 \mathrm{~d}$ & $3.12 \mathrm{c}$ & $0.68 \mathrm{~b}$ \\
Missouri & Moist & $0.58 \mathrm{a}$ & $0.022 \mathrm{ab}$ & $0.52 \mathrm{ab}$ & $0.99 \mathrm{a}$ & $0.86 \mathrm{~d}$ \\
Ontario & Dry & $0.59 \mathrm{a}$ & $0.021 \mathrm{a}$ & $0.46 \mathrm{a}$ & $1.23 \mathrm{ab}$ & $0.85 \mathrm{~d}$ \\
Ontario & Moist & $0.94 \mathrm{a}$ & $0.023 \mathrm{ab}$ & $0.50 \mathrm{ab}$ & $1.80 \mathrm{~b}$ & $0.80 \mathrm{~cd}$ \\
Tennessee & Dry & $1.86 \mathrm{~b}$ & $0.029 \mathrm{~cd}$ & $0.60 \mathrm{bc}$ & $2.83 \mathrm{c}$ & $0.71 \mathrm{bc}$ \\
Tennessee & Moist & $3.87 \mathrm{c}$ & $0.049 \mathrm{f}$ & $0.99 \mathrm{e}$ & $3.91 \mathrm{~d}$ & $0.61 \mathrm{a}$ \\
\hline Means & & 1.21() & 0.029 & 0.62 & 2.16 & 0.77 \\
\hline F (9,80) & & 19.881 & 16.423 & 15.533 & 13.375 & 12.101 \\
Model & & $<\mathbf{0 . 0 0 1}$ & $<\mathbf{0 . 0 0 1}$ & $<\mathbf{0 . 0 0 1}$ & $<\mathbf{0 . 0 0 1}$ & $<\mathbf{0 . 0 0 1}$ \\
Seed Source & & $<\mathbf{0 . 0 0 1}$ & $<\mathbf{0 . 0 0 1}$ & $<\mathbf{0 . 0 0 1}$ & $<\mathbf{0 . 0 0 1}$ & $<\mathbf{0 . 0 0 1}$ \\
Preconditioning & & 0.417 & 0.950 & 0.676 & 0.063 & 0.117 \\
Seed Source $\times$ & & $<\mathbf{0 . 0 0 1}$ & $\mathbf{< 0 . 0 0 1}$ & $<\mathbf{0 . 0 0 1}$ & $<\mathbf{0 . 0 0 1}$ & $<\mathbf{0 . 0 0 1}$ \\
Preconditioning & & & & & & \\
\hline
\end{tabular}

${ }^{1}$ Means $(n=30)$ in a column with same letter are not different $(p>0.05)$ with a Fisher's Protected LSD.

${ }^{2}$ Significance probabilities from the F statistic from an ANOVA. Significant values $(p<0.05)$ bold. 
Table 6. Relative water content at zero turgor $\left(\mathrm{RWC}_{0}\right)$, osmotic potential at full turgor ( $\left.\Psi_{100}\right)$, and osmotic potential at zero turgor $\left(\Psi_{0}\right)$. (standard error of the mean)

\begin{tabular}{lllll}
\hline Seed source & $\begin{array}{l}\text { Sample } \\
(\mathrm{n})\end{array}$ & $\mathrm{RWC}_{0}(\%)^{1}$ & $\Psi_{100}(\mathrm{Mpa})^{1}$ & $\Psi_{0}(\mathrm{Mpa})^{1}$ \\
\hline Caddo & 5 & $93.1(0.5) \mathrm{a}$ & $-1.18(0.09) \mathrm{bc}$ & $-1.34(0.08) \mathrm{bc}$ \\
Iowa & 4 & $93.7(0.5) \mathrm{ab}$ & $-1.51(0.09) \mathrm{a}$ & $-1.68(0.10) \mathrm{a}$ \\
Missouri & 5 & $94.9(0.1) \mathrm{bc}$ & $-1.21(0.09) \mathrm{bc}$ & $-1.35(0.09) \mathrm{bc}$ \\
Ontario & 6 & $94.9(0.3) \mathrm{bc}$ & $-1.42(0.06) \mathrm{ab}$ & $-1.56(0.06) \mathrm{ab}$ \\
Tennessee & 4 & $95.0(0.6) \mathrm{c}$ & $-0.98(0.08) \mathrm{c}$ & $-1.12(0.09) \mathrm{c}$ \\
\hline Mean & & $94.3(0.2)$ & $-1.27(0.05)$ & $-1.42(0.05)$ \\
\hline F $(4,19)^{2}$ & & 4.93 & 6.04 & 5.97 \\
p-value & & $\mathbf{0 . 0 0 7}$ & $\mathbf{0 . 0 0 3}$ & $\mathbf{0 . 0 0 3}$ \\
\hline
\end{tabular}

${ }^{1}$ Means $(n=24)$ in the same column with a similar letter are not significantly different $(\mathrm{p}>0.05)$ level using

a Duncan test.

${ }^{2}$ Significance probabilities from the F statistic from an ANOVA. Significant values $(\mathrm{p}<0.05)$ in bold.

\subsection{Biomass Development and Allocation}

Biomass portioning varied by seed source and preconditioning. Above ground biomass did not differ prior to water stress preconditioning. The black maple source grew more root mass absolutely and proportionately compared with seedlings of the other sugar maple sources. This finding was similar to that of Hilaire and Graves [19] with black maple from Iowa sources. We found that in response to mild water stress preconditioning, the black maple Iowa source responded by shifting biomass development to root systems proportionally more than did the other sources. The Iowa source had a greater R:S than the other sugar maple sources consistently with prior studies $[19,23]$. The Ontario and Iowa sources responded to mild water stress imposed through the dry preconditioning cycles by increasing their R:S, while the southwestern sugar maple sources did not. Graves [23] observed seedlings of black maple (from west central Iowa) to have a greater R:S than sugar maple from further north in Minnesota both before and after imposed water stress. Sugar maple allocated greater carbon partitioning to leaf and stem tissue under moist conditions and black maple preferentially allocated to root growth. This was consistent with our findings. In contrast, the Caddo, Missouri, and Tennessee sugar maple sources responded alike with no significant change in their R:S or root mass when exposed to experimentally imposed water stress. Pallardy and Rhoads [49] also found no difference in the R:S of sugar maple seedlings from Missouri that were exposed to either continually moist soil or subjected to repeated drying cycles for ten weeks. The Ontario and Iowa seedlings were apparently more sensitive to water stress with respect to biomass allocation, having increased their R:S and lowered their SLA as a result of water stress preconditioning. It could also be surmised that the Caddo, Missouri, and Tennessee sources were not water stressed to the extent of the Ontario and Iowa sources due to greater efficiency in water use.

An increase in the R:S of woody plants often occurs in response to water stress [39]. Intrinsically high R:S or plastic increases due to water stress are mechanisms often associated with enhancing water stress resistance. However, the R:S is not always consistently higher in more water stress resistant tree species or ecotypes [39, 50]. Water stress resistance is conferred by many different morphological and physiological traits [51]. In sugar maple, rooting patterns [39, 52, 53, 54], leaf cuticle dimensions [2], leaf abscission [49], hydraulic lift [55], and mycorrhizal symbiosis are all factors that could influence water stress resistance of maples in nature but which were beyond the scope of this study.

The sugar and black maple sources had a similar SLA of approximately $200 \mathrm{~cm}^{2} \cdot \mathrm{g}^{-1}$ (range 183 to $232 \mathrm{~cm}^{2} \cdot \mathrm{g}^{-1}$ ) under moist preconditioning. Under dry preconditioning the 
SLA decreased for the Ontario $\left(171 \mathrm{~cm}^{2} \cdot \mathrm{g}^{-1}\right)$ and Iowa $\left(144 \mathrm{~cm}^{2} \cdot \mathrm{g}^{-1}\right)$ sources. Plants with a lower SLA are characteristic of drought avoiders [51]. However, a leaf with a higher SLA coupled with a high photosynthetic rate provides a highly efficient assimilation system [56] At the beginning of the water stress treatment the Caddo sugar maple, which had a high SLA relative to other maples in this study, had a high rate of A. Thus, the Caddo sugar maple may have a highly efficient carbon assimilation system with respect to water use and this attribute might explain enhanced water stress resistance in the Caddo sugar maple.

4.2 Plant gas exchange

We showed that a northeasterly sugar maple source and black maple responded similarly. Our findings with the Ontario sugar maple and Iowa black maple source were similar to a finding by $[19,57]$. In that study, stomatal conductance decreased for black maple as a putative mechanism for drought avoidance. Our findings are not consistent with Ware [25, 26] and Graves [23] who suggested that black maple trees from Iowa may have better water stress resistance. Our results and those of Pair [18] do not support the suggestion that black maple is a more water stress resistant maple. Pair [18] compared young sugar maple and black maple trees growing in Kansas over an 8-year period and found black maple seedlings and the black maple cultivar 'Green Column' to have the least increase in stem caliper and height. In addition, during a drought Pair [18] found the black maple sources had the lowest pre-dawn and mid-day xylem water potential and also tended to have the most severe leaf scorch and intermediate leaf tatter. Nonetheless, increased root to shoot ratios, if they occur in sapling and mature black maple trees, could provide a mechanism to avoid drought, thus explaining multiple observations of this trait in mature specimens of black maple.

We found Gs was maintained in the southwesterly sugar maple ecotypes more so than the Ontario and Iowa source. Hilaire [57] found water stress resulted in a $48 \%$ Gs decline in a black maple source from Iowa. Sugar maple stomates have been observed to close faster, open more slowly, and remain closed longer in response to water deficits in comparative studies [3, 4, 58, 59, 60, 61]. Further, Lechowicz and Ives [62] found that sugar maple seedlings in a nursery that were subjected to mild water stress stabilized their internal $\mathrm{CO}_{2}$ concentration by varying their stomatal conductance, which suggests greater stomatal sensitivity to water stress. In our study, during the mid-portion of the imposed water stress the internal $\mathrm{CO}_{2}$ concentration increased faster in the Ontario and Iowa sources in comparison to the dry preconditioned Caddo, Missouri, and Tennessee sources.

The dry preconditioned Oklahoma and Missouri sources maintained a higher A and WUE during the mid-portion of the simulated water stress, declining less rapidly in comparison to their moist preconditioned seedlings. The Tennessee ecotype, regardless of preconditioning treatment, also declined less rapidly than other ecotypes. Preconditioning had no effect on these parameters for the Ontario or Iowa ecotypes. Ni and Pallardy [63] found the mesophyll in sugar maple from Missouri to be more sensitive to dehydration than post oak (Quercus stellata), because stomatal limitation decreased under water stress. The $\mathrm{Ci}$ of the sugar maple leaves increased and remained high even after 5 days of rehydration in their study suggesting mesophyll damage. Further, carboxylation efficiency remained low and the $\mathrm{CO}_{2}$ compensation point was higher after rewatering. It remains to be determined if ecotypic differences in mesophyll sensitivity to water stress for sugar and black maple exist.

4.3 Leaf water potential

Preconditioning can result in $\mathrm{Y}_{0}$ and $\mathrm{Y}_{100}$ changes $[38,39,40]$, however preconditioning did not result in a difference between sources in $\mathrm{Y}_{0}$ and $\mathrm{Y}_{100}$ in this study, possibly since we imposed a mild water stress. We withheld watering until leaf wilting and then rewatered plants. It is possible that if we imposed greater water stress by letting seedlings persist in a wilted stage for several days, a preconditioning effect might have resulted in osmotic adjustment. As an adaptive feature, osmotic adjustment increases the ability to extract water from dry soil, increasing the ability to maintain cell turgor [39]. Osmotic adjustment in sugar maple has been observed by Kolb et al. [64] in a greenhouse seedling 
study (Pennsylvania source). In contrast, osmotic adjustment was not detected by Bahari et al. [5] in a forest field study (Missouri) nor by Tschaplinski et al. [65] with experimental greenhouse seedlings. Ellsworth and Reich [66] found the Yo to differ among sugar maple trees growing in understory, gap, and clear-cut forest habitats, where trees in the sunnier clearcut area had the lowest values. However, osmotic adjustment did not occur in sugar maple within a site during a drought the following year.

The similarity in leaf water potential with black maple from Iowa to an Ontario sugar maple source in this study is consistent with Pair [18] who found xylem water potential (pre-dawn and midday) were lowest in black maple sources and eastern sugar maple sources under water stress. These sources also had the greatest leaf tattering damage following a mid-summer drought [67]. Our results (-1.12 to -1.68) are within the range reported for $Y_{0}$ of sugar maple trees grown under moist conditions (-0.81 to $\left.-2.18 \mathrm{MPa}\right)$ and dry conditions $(-0.97$ to $-2.44 \mathrm{MPa})[5,64,66]$. The leaf development stage can influence $Y_{0}$ with Tyree et al. [68] finding $\mathrm{Y}_{0}$ increased from -1.00 MPa in developing leaves to -2.00 $\mathrm{MPa}$ in mature leaves in sugar maple. The Iowa (black maple) and Ontario sources had the lowest $Y_{0}$, suggesting they are less tolerant of water stress than the southwestern studied sources. All sources in this study were less negative than the mean $-2.06 \mathrm{MPa}$ (moist conditions) to $-2.54 \mathrm{MPa}$ (dry conditions) generally associated with North American tree species [40].

No significant difference in the RWC 0 occurred between moist or dry preconditioned seedlings and among sources. The sources had an average $\mathrm{RWC}_{0}$ of 0.944 . This is near the $0.96 \mathrm{RWC}_{0}$ observed by Kolb et al. [64] for greenhouse grown sugar maple seedlings under moist conditions. In contrast, values for the $\mathrm{RWC}_{0}$ ranging between 0.77 and 0.90 have been reported for a field study of sugar maple in understory, gap, and clearcut habitats [66].

\section{Conclusions}

Sugar maple ecotypes seedling from Oklahoma, Missouri, and Tennessee regulated water stress to a greater extent through gas exchange and greater water use efficiency in comparison to the Ontario and Iowa ecotypes. Our finding that black maple was more susceptible to water stress than southwestern sugar maple sources is consistent with the findings of Pair [18] and do not support a popular notion that black maple has generally greater water stress tolerance than other sugar maples, at least in the seedling stage or via leaf physiological mechanisms. However, if a high root to shoot ratio persists into maturity in black maple trees, the observations of greater water stress tolerance of this sugar maple subspecies might be explained. The agreement between our physiological assays of seedlings and the results of a study of water stress response of sugar maple cultivars in a field trial [18] indicate that seedling assays may be predictive of long-term physiological adaptations affording sugar maple ecotypes drought and dry site tolerance. Finally, our results suggest that differences in WUE rather than inherent or induced differences in protoplasmic tolerance of water stress resulted in water stress hardiness differences among sugar maple ecotypes. 


\section{References}

1. Godman R.W., Yawney H.W., Tubbs C.H. Acer saccharum Marsh. Sugar Maple. In Silvics of North America, vol. 2. Hardwoods; Burns R.M., Honkala B.H. Eds. Agriculture Handbook 654. Washington, D.C., USDA Forest Service. 1990, pp. 78-91.

2. Dirr, M.A. Manual of woody landscape plants: their identification, ornamental characteristics, culture, propagation, and uses. 6th edition. Stipes Publishing L.L.C. Champaign, IL. 2009, 1325 pp.

3. Phelps, J.E., Chambers J.L., Hinckley T.H. Some morphological, ecological, and physiological traits of four Ozark forest species. In Proceeding 1st Central Hardwood Forest Conference; J.S. Fralish, G.T. Weaver, and R.C. Schlesinger Eds. Southern Illinois University. Carbondale, IL. 1976, pp. 231-242.

4. Hinckley, T.M., Dougherty P.M., Lassoie J.P., Roberts J.E., Teskey R.O. A severe drought: impact on tree growth, phenology, net photosynthetic rate and water relations. American Midland Naturalist, 1979, 102, 307-316.

5. Bahari, Z.A., Pallardy S.G., Parker W.C. Photosynthesis, water relations and drought adaptation in six woody species of oakhickory forests in central Missouri. Forest Science, 1985, 31, 557-569.

6. Hallett, R.A., Bailey S.W., Horsley S.B., Long R.P. Influence of nutrition and stress on sugar maple at a regional scale. Canadian Journal of Forest Research, 2006, 36(9), 2235-2246.

7. St. Clair S.B., Sharpe W.E., Lynch J.P. Key interactions between nutrient limitation and climatic factors in temperate forests: a synthesis of the sugar maple literature. Canadian Journal Forest Research, 2008, 38(3), 401-414.

8. Graignic N., Tremblay F., Bergeron Y. Influence of northern limit range on genetic diversity and structure in a widespread North American tree, sugar maple (Acer saccharum Marshall). Ecology and Evolution, 2018, 8(5), 2766-2780. DOI: 10.1002/ece3.3906

9. Collin, A., Messier C., Kembel S.W., Bélanger N. Can sugar maple establish into the boreal forest? Insights from seedlings under various canopies in southern Quebec. Ecosphere, 2018 9(1), e02022. 10.1002/ecs2.2022

10. Rich, S., Walton, G.S. Decline of curbside sugar maples in Connecticut. Journal of Arboriculture, 1979, 5(12), $265-268$.

11. Close R.E., Nguyen P.V., Kieblaso J.J. Urban vs. natural sugar maple growth: I. Stress symptoms and phenology in relation to site characteristics. Journal of Arboriculture, 1996, 22(3), 144-150.

12. Close R.E., Kieblaso J.J., Nguyen P.V., Schutzki R.E. Urban vs. natural sugar maple growth: II. Water relations. Journal of Arboriculture, 1996, 22(4), 187-192.

13. Horsley, S.B., Long R.P., Bailey S.W., Hallett R.A., Wargo P.M. Health of eastern North American sugar maple forests and factors affecting decline. Northern Journal of Applied Forestry, 2002, 19(2), 34-44.

14. Kriebel, H.B. Patterns of genetic variation in sugar maple. Ohio Agricultural Experiment Station. Research. Bulletin 791. 1957, 56 pp.

15. Kriebel, H.B. Twenty-year survival and growth of sugar maple in Ohio seed source tests. Ohio Agricultural Experiment Station. Research Circular 206. 1975, 9 pp.

16. Scanlon, D.H. Seed source effects on sugar maple. American Nurseryman, 1976, 143, p. 13, 76, 78

17. Dent, $\mathrm{T}$., Adams R. Relationships of two isolated groups of sugar maples (Acer saccharum Marshall ssp. saccharum) in west central Oklahoma to eastern and western species. Rhodora, 1983, 85(844), 439-456.

18. Pair, J.C. Stress tolerant trees for the southern great plains. Journal of Arboriculture, 1994, 20, 130-133.

19. Hilaire, R. St. and Graves W.R. Stability of provenance differences during development of hard maple seedlings irrigated at two frequencies. Hortscience, 2001, 36(4), 654-657.

20. Le Duc, A. and Pair J. 'John Pair' and 'Autumn Splendor' sugar maples. Hortscience, 2000, 35(5), 970-971.

21. Sanford, W.E. and Selnick D.L. Estimation of evapotranspiration across the conterminous United States using a regression with climate and land-cover data. Journal of the American Water Resources Association, 2013, 49(1), 217-230.

22. Curtis, J.T. The Vegetation of Wisconsin. The University of Wisconsin Press. Madison, WI. 1959, 657 pp.

23. Graves, W.R. Seedling development of sugar maple and black maple irrigated at various frequencies. Hortscience, 1994, 29, $1292-$ 1294.

24. Kriebel, H.B. and Gabriel W.J. Genetics of sugar maple. USDA Forest Service Research Paper WO-7. 1969, 17 pp.

25. Ware, G.H. Acer saccharum subspecies nigrum: meritorious midwestern maple. In Proceedings Metropolitan Tree Improvement Alliance (METRIA). H.D. Gerhold Ed. New York Botanical Garden. 1983, METRIA 3, pp. 1-6.

26. Ware, G.H. Ecological basis for selecting urban trees. Journal of Arboriculture, 1994, 20, 98-103.

27. Thompson, R.S., Anderson K.H., Pelltier R.T., Strickland L.E., Shafer S.L., Bartlein P.J., McFadden A.K. Atlas of relations between climatic parameters and distributions of important trees and shrubs in North America-Revisions for all taxa from the United States and Canada and new taxa from the western United States. U.S. Geological Survey Professional Paper 1650-G. 2015, http://dx.doi.org/10.3133/pp1650G.

28. Hightshoe, G.L. Native trees, shrubs and vines for urban and rural America: a planting design manual for environmental designers. Van Nostrand Reinhold, New York, USA. 1988, 832 pp.

29. Bassuk, N., Curtis D.F., Marranca, B.Z. Neal B. Recommended urban trees: site assessment and tree selection for stress tolerance. Urban Horticulture Institute, Cornell University, Ithaca, NY. 2009, http://www.hort.cornell.edu/uhi/outreach/recurbtree/pdfs/ recurbtrees.pdf (accessed on 5, March, 2021)

30. Niinemets U and Valladares F. Tolerance to shade, drought, and waterlogging of temperate Northern Hemisphere trees and shrubs. Ecological Monographs, 2006, 76(4), 521-547, https://doi.org/10.1890/0012-9615(2006)076[0521:TTSDAW]2.0.CO;2

31. Sjöman, H., Hirons A.D., Bassuk N.L. Urban forest resilience through tree Selection: variation in drought tolerance in Acer. Urban Forestry and Urban Greening, 2015, 14, 858-865, http://dx.doi.org/10.1016/j.ufug.2015.08.004. 
32. Skepner, A., Krane D. RAPD reveals genetic similarity of Acer saccharum and Acer nigrum. Heredity, 1998, 80, 422-428, https://doi.org/10.1046/j.1365-2540.1998.00312.x

33. Gabriel, W.J. Acer nigrum Michx. f. Marsh. Black Maple. In Silvics of North America, vol. 2. Hardwoods; Burns R.M., Honkala B.H. Eds. Agriculture Handbook 654. Washington, D.C., USDA Forest Service. 1990, pp. 46-52.

34. Over, W.H. Flora of South Dakota. University of South Dakota. Vermillion, SD. 1932, 161 pp.

35. Slabaugh, P.E. Silvical characteristics of black maple. USDA Forest Service Station Paper \#66. 1958, 9 pp.

36. Deam, C.C. Flora of Indiana. William. B. Burford Printing Company. Indianapolis, IA. 1940, 1236 pp.

37. Aikman, J.M., Smelser A.W. The structure and environment of forest communities in central Iowa. Ecology.,1938, 19, 141-150

38. Kozlowski, T.T. and S.G. Pallardy. 2002. Acclimation and adaptive responses of woody plants to environmental stresses. The Botanical Review. 68(2): 270-334.

39. Pallardy, S. Physiology of woody plants. Academic Press. Cambridge, MA. 2008, 464 pp. https://doi.org/10.1016/B978-0120887651.50001-4.

40. Abrams, M.D. Sources of variation in osmotic potentials with special reference to North American tree species. Forest Science, 1988, 34, 1030-1046.

41. Janerette, C.A. The effects of water soaking on the germination of sugar maple seeds. Seed Science Technology, 1979, 7, 341-346.

42. Olmsted, C.E. Experiments on photoperiodism, dormancy, and leaf age and abscission in sugar maple. Botanical Gazette, 1951, $112,365-393$.

43. Jackson, S.D. Plant responses to photoperiod. The New Phytologist, 2009, 181(3), 517-531.

44. NRCS. Natural Resources Conservation Service, United States Department of Agriculture. Official Soil Series Descriptions. Drummer Series. USDA National Cooperative Soil Survey. 2015, https://soilseries.sc.egov.usda.gov/OSD Docs/D/DRUMMER.html, (accessed 15, March, 2021)

45. Hoagland, D.R., Arnon D.I. The water-culture method for growing plants without soil. California Agricultural Experiment Station. Circular 347, 2nd Edition. 1950, 32 pp.

46. Richter, H. A diagram for the description of water relations in plant cells and organs. Journal Experimental Botany, 1978, 29, 11971203.

47. Rice, E.L. The microclimate of sugar maple stands in Oklahoma. Ecology, 1962, 43, 19-25.

48. Hensley, D.L., Wiest S.C., Robbins J.A., Long C.E., Pair J.C., Schlegel A.J. Evaluation of trees for the central plains. Journal of Arboriculture, 1992, 18:49-55.

49. Pallardy, S.G., Rhoads J.L. Morphological adaptations to drought in seedlings of deciduous angiosperms. Canadian Journal Forest Research, 1993, 23, 1766-1774.

50. Barton, A.M., Teeri J.A. The ecology of elevational positions in plants: drought resistance in five montane pine species in southeastern Arizona. American Journal Botany, 1993, 80, 15-25.

51. Larcher, W. Physiological plant ecology ecophysiology and stress physiology of functional groups. Fourth Ed. Springer-Verlag. Berlin Heidelberg. 2003, 514 pp.

52. Rhodenbaugh, E.J., Pallardy S.G. Eco-physiology of Acer saccharum trees on glade-like sites in central Missouri. In Proceedings 9th Central Hardwood Forest Conference. A.R. Gillespie, Parker G.R., Pope P.E. Eds. USDA General Technical Report NC-161. 1993, pp. 76-82.

53. Hardin, J.W., Leopold D.J, White F.M. Harlow and Harrar's Textbook of dendrology 9th Edition. McGraw Hill. New York. 2001, 534 pp.

54. Day, S. D., Wiseman P.E., Dickinson S.B., Harris J.R. Contemporary concepts of root system architecture of urban trees. Arboriculture \& Urban Forestry, 2010, 36(4), 149-159.

55. Dawson, T.E. Hydraulic lift and water use by plants: implications for water balance, performance and plant-plant interactions. Oecologia, 1993, 95, 565-574.

56. Ledig, F.T., Korbobo D.R. Adaptation of sugar maple populations along altitudinal gradients: photosynthesis, respiration, and specific leaf weight. American Journal Botany, 1983, 70, 256-265.

57. Hilaire, R. St. Ecophysiology and genetic diversity of hard maples. Indigenous to eastern North America. PhD Dissertation. Iowa State University. 1998, 100 pp.

58. Davies, W.J., Kozlowski T.T. Stomatal responses of five woody angiosperms to light intensity and humidity. Canadian Journal Botany, 1974, 52, 1525-1534.

59. Davies, W.J., Kozlowski T.T. Stomatal responses to changes in light intensity as influenced by plant water stress. Forest Science, 1975, 21, 129-133.

60. Kozlowski, T.T., Davies W.J., Carlson, S.D. Transpiration rates of Fraxinus americana and Acer saccharum leaves. Canadian Journal Forest Research, 1974, 4, 259-267.

61. Pereira, J.S., Kozlowski T.T. Influence of light intensity, temperature, and leaf area on stomatal aperture and water potential of woody plants. Canadian Journal Forest Research, 1977, 7, 145-153.

62. Lechowicz, M.J., Ives N.E. Comparative ecology of drought response in hardwood trees: Acer saccharum versus Fraxinus americana. In Structural and functional responses to environmental stresses. K.H. Kreeb, Richter H., Hinckley T.M. Eds. SPB Academic Pub. b. Hauge, Netherlands. 1989, pp. 283-292.

63. Ni, Bing-Rui, Pallardy S.G. Stomatal and nonstomatal limitations to net photosynthesis in seedlings of woody angiosperms. Plant Physiology 1992, 99, 1502-1508.

64. Kolb, T.E., McCormick L.H., Shumway D.L. Physiological responses of pear thrips-damaged sugar maples to light and water stress. Tree Physiology, 1991, 9, 401-413. 
65. Tschaplinski, T.J., Stewart D.B., Norby P.J. Interactions between drought and elevated CO2 on osmotic adjustment and solute concentrations of tree seedlings. New Phytologist, 1995, 131, 169-177.

66. Ellsworth, D.S., Reich P.B. Water relations and gas exchange of Acer saccharum seedlings in contrasting natural light and water regimes. Tree Physiology, 1992, 10, 1-20.

67. Conley, M., Paparozzi, E., Pair, J., Stroup, W. Leaf tatter in Acer saccharum: An anatomical link. International Journal of Plant Sciences, 1995, 156(3), 303-310.

68. Tyree, M.T., Cheung Y.N.S., MacGregor M.E., Talbot A.J.B. The characteristics of seasonal and ontogenetic changes in the tissuewater relations of Acer, Populus, Tsuga, and Picea. Canadian Journal Botany, 1977, 56, 635-647. 